\title{
Effects of Religious Discrimination and Fear for Safety on Life Satisfaction for Muslim Americans
}

\author{
Ramy Bassioni* and Kimberly Langrehr ${ }^{\dagger}$
}

\begin{abstract}
The purpose of the current study was to examine the relationship between two forms of religious discrimination (religious prejudice and environmental discrimination) and life satisfaction in a sample of Muslim Americans. Based on the framework of minority stress theory, we hypothesized that higher levels of religious prejudice (distal stressor) and environmental discrimination would significantly relate to higher fear for safety (proximal stressor) and, in turn, would relate to lower life satisfaction. A total of 192 Muslim American participants (Age $M=27.87$ ) completed an online survey about their experiences. Women made up almost $75 \%$ of the sample. Findings revealed that higher religious prejudice as well as environmental discrimination were both significantly related to lower life satisfaction and that fear for safety partially mediated both of these relationships. Findings help illustrate that Muslim Americans are impacted by the socialpolitical climate of Islamophobia and can experience religious discrimination in different ways. In addition, women and younger participants expressed higher fear for safety when compared to men and older participants. Professionals who work with individuals from the Muslim community are encouraged to consider the chronic and ongoing impact of stress that Muslim Americans face especially within some Islamophobic environments in the United States.
\end{abstract}

\section{Keywords}

Muslim American $\bullet$ religious discrimination $\bullet$ hate crimes $\bullet$ life satisfaction

\section{Introduction}

Consisting of around 1.6 billion Muslims, Islam is considered the second largest religion in the world, following Christianity (Ali, Liu, \& Humedian, 2004; Lipka, 2017). In the United States, Muslims are estimated to range anywhere from three to seven million (Mohamed, 2016; Rosentiel, 2007), with a majority identifying as immigrants (Pew Research Center, 2018). Although the 1960s introduced a large wave of Muslim immigrants to the United States, Islam as an "outsider" religion, rarely garnered public attention until the Iran hostage crisis through the 1980s, through the 1990s and events of $9 / 11$ which solidified the start of Islamophobic narratives in both mainstream and political atmospheres (Ahmad, 2009). For example, new

*University of Missouri, Kansas City, rbassioni@mail.umkc.edu

†University of Missouri, Kansas City, langrehrk@umkc.edu

doi: $10.3998 / \mathrm{jmmh} .133$

Conflicts of interest:

The authors have no conflicts of interest to disclose. 
words (e.g., anti-Muslim) and terminology (e.g., Islamophobia) have become commonplace to describe the fear and hatred toward Muslims (Every \& Perry, 2014) while various prejudiced efforts such as the "Campaign for a Muslim Free America" and "Muslim Free Zones" have also emerged (Council on American-Islamic Relations [CAIR], 2015). Furthermore, when reporting on Islam-related news stories, media outlets often use stigmatizing language (Dunn, Klocker, \& Salabay, 2007; Kalek, Mak, \& Khawaja, 2010) and pair images of Muslim women in hijabs when referring to "terrorists" (Ahmad, 2009).

Given this prejudiced climate, hate crimes against Muslims have increased substantially over the last 20 years (Abu-Ras \& Suarez, 2009; Ibish, 2008) particularly as Muslims began to be scrutinized as a threat to national security (Bakalian \& Bozorgmehr, 2011). In the second quarter of 2018 alone, CAIR received 1006 reports of bias incidents against Muslims and reported a 21\% increase in hate crimes against Muslims (CAIR, 2018). Given the increase in Islamophobic sentiments within the United States, it is not overly surprising that Muslims tend to be highly misunderstood and often misidentified by the American public (Hood, 2009; Younis, 2015). For example, Islam is often depicted as a monolithic religion, yet Muslims are significantly diverse and represent a variety of sects, traditions, social class markers, and ethnic backgrounds (Platt, 2007; Wang, Raja, \& Azhar, 2019). Furthermore, racial considerations for many Muslim Americans can be complex and confusing given that the U.S. government classifies Arab Americans as "White" (Bakalian \& Bozorgmehr, 2011). Muslims with South Asian heritage (e.g., India, Pakistan, etc.) fall under the U.S. census definition of "Asian" (i.e., having origins in the Far East, Southeast Asia, or the Indian subcontinent) yet they often share more cultural traditions with Muslims from the Middle East than from East Asia (Bakalian \& Bozorgmehr,2011).

Given these misperceptions, Muslim Americans face multiple forms of discrimination and harassment that are likely to have negative consequences on their mental health and functioning (Amer \& Bagasra, 2013; Bakalian \& Bozorgmehr, 2011). In particular, experiencing ongoing external expressions of individual prejudice (e.g., discrimination, harassment, violence) has been linked to a variety of adverse psychological and physical consequences among underrepresented groups (Pascoe \& Richman, 2009; Schmitt, Branscombe, Postmes, \& Garcia, 2014). Given the misperceptions of Islam as a threat to the values of many Americans (Rubenstein, 2004), we propose that it is particularly important to consider the impact that these misperceptions have on Muslims who are perceived and treated unfairly within Islamophobic environments of the United States. According to the tenets of minority stress theory (Meyer, 1995; 2003), individuals who hold values considered to diverge from the dominant culture are likely to experience their social climate as hostile (e.g., Islamophobia), and are subject to ongoing forms of discrimination and injustice that have adverse consequences on their mental health. Therefore, the purpose of the current study is to explore the relationship between different forms of religious discrimination and life satisfaction and whether appraising threats to their safety helps explain this relationship.

\section{Discrimination and Minority Stress among Muslim Americans}

Given the widespread nature of Islamophobia in the recent sociopolitical climate, it seems imperative to consider the influence of minority-related stress in understanding the discriminatory experiences faced by Muslim Americans. Minority stress theory is a framework that explains and accounts for marginalization, stress, and stigma faced by minority groups (Meyer 2003; Parent et al., 2018). In particular, minority stress can be characterized as the marginalization and stigmatization faced by minority groups when their values, beliefs, and practices are deemed to conflict with that of the mainstream culture (Meyer, 1995; Pearlin, 1989). According to minority stress theory, stigmatized individuals face stressors in the form of harassment and discrimination that lends to higher risk for negative mental health outcomes (Lehavot \& Simoni, 2011; Williams 
et al., 2005). Being perceived as a member of a marginalized group (e.g., racial, ethnic, religious, or sexual minorities) has been known to increase the likelihood of expecting rejection from the dominant society and interpreting events as discriminatory (Mendoza-Denton et al., 2012).

Although the narrative of religious freedom and the separation of church and state are foundational to this country, the United States has been referred to as a largely Christian nation (Curtis IV, 2009), such that approximately 65\% to 70\% of Americans identify with some form of Christianity (Pew Research Center, 2016). Throughout U.S. history, certain Christian identities can be linked to disproportionate amount of sociopolitical power, for example in that all but two of the 46 presidents have been Protestants (Pew Research Center, 2020). Furthermore, many Americans' perceptions of religion have been historically viewed through a Christian lens, which has placed other religions in a position of being viewed as "different" and incompatible with American values (Cainkar, 2002; Rubenstein, 2004). In addition, Westernized media has often referred to terrorism when discussing Islam and Muslims, making the faith synonymous with most attacks in Western countries (Poynting et al., 2004).

Although minority stress theory was originally created to help explain the experiences of discrimination among sexual minorities (Meyer, 2003), the theoretical tenets can be used to understand and explain how other groups perceived to be different from the dominant society experience stress (Carr \& Friedman, 2005). Experiences faced by religious minorities can result in the same health risks as other marginalized groups presented through the minority stress model. The scrutiny placed on Muslims since $9 / 11$ has undoubtedly contributed to the rise in overt forms of violence against Muslim communities based on depictions of Islam as a foreign belief system that contradicts American values (Cainkar, 2002; Rubenstein, 2004). In particular, Islamic values and practices are typically viewed as conflicting with American culture (Ahmad, 2009), and this perceived contention (with dominant values) can lend to greater stress and fewer resources for underrepresented communities (Williams, Neighbors, \& Jackson, 2003). Given the external stresses of facing discriminatory treatment and anti-Muslim attitudes, Muslim Americans are likely to experience a stress process that is likely to affect their overall wellbeing. Indeed, existing studies that have explored the impact of discrimination among Muslim Americans suggest that greater experiences with religious discrimination have been related to higher rates of depression (Hodge, Zidan, \& Husain, 2016) and PTSD symptoms (Abu-Ras \& Suarez, 2009; Lowe, Tineo, Bonumwezi, \& Bailey, 2019), lower self-esteem (Ghaffari \& Çiftçi, 2010), and physical health problems (Kira et al., 2010; Sheridan, 2006). Most research in this area has examined discrimination from an interpersonal standpoint such that participants are asked about their experiences with microaggressions (Nadal et al., 2012) and being harassed or treated unfairly based on their Muslim identity (Ghaffari \& Çiftçi, 2010; Lowe et al. 2019). In addition to facing ongoing interpersonal religious discrimination from people in society, Muslim Americans face prejudice and bias through repercussions of sensationalist news outlets and other publicized forums. For example, mainstream media tens to further perpetuate Islamophobic sentiments by framing Muslim Americans within the context of terrorism and violence (Laird, et al., 2013; Mercier, et al., 2018; Shaver, Sibley, Osborne, \& Bulbulia, 2017). While interpersonal discrimination can result in instances of harassment and hate crimes from individuals in society, prejudicial depictions in the media can lead to systemic discrimination and policies aimed at impacting Muslim Americans. These different types of discrimination impact and affect Muslim Americans differently.

Within the framework of minority stress, it is important to underscore that Muslim Americans are likely to experience different variations of minority-related stress that can be categorized as distal and proximal stressors. Distal stressors (e.g., discrimination, violence, Islamophobic attitudes in the media) are considered external influences that target an individual based on their 
identity whereas proximal stress is considered a byproduct of distal stress that relies on a person's internal and subjective appraisals of their experiences with discrimination (Meyer, 2003). In particular, by sensing ongoing threats to safety, victims of discrimination are likely to internalize their distress (Major, Kaiser, O’Brien, \& McCoy, 2007). In one of the only studies on Muslim Americans that examined indicators of distress within a minority stress framework, the results revealed a positive and significant relationship between perceived discrimination and negative psychological symptoms (Rippy \& Newman, 2006). In addition, this study considered multiple forms of religious discrimination (i.e., interpersonal prejudice, environment, and bicultural identification) and found that higher forms of religious discrimination positively correlated with higher levels of suspicion, mistrust, and wariness. In their conclusions, the authors emphasized that when working with Muslim Americans, it is essential to consider the realities of their environmental context when interpreting any hypervigilant behaviors (Rippy \& Newman, 2006).

\section{Fear for Safety}

One of the unique and devastating aspects of Islamophobia compared to other forms of prejudice is its characterization of being an active threat to America's religious and national values and security (Wang et al., 2019). Within the framework of minority stress theory (Meyer, 1995; 2003), developing concerns for personal safety would not be an out-of-proportion response for Muslims given the widespread stigma, violence, and loss linked to Islamophobia (Abu-Ras \& Suarez, 2009). Indeed, following 9/11, Muslim Americans have reported feeling less safe in society (Abu-Ras \& Abu-Bader, 2008; Ali et al., 2004). Furthermore, studies have found evidence that Muslim women indeed experience and are impacted by internal stressors causing them to have to choose whether or not to remove their hijab or conceal their religious identity due to feelings of hypervigilance and feeling unsafe (Ghaffari \& Çiftçi, 2010).

\section{Purpose of Study}

Given the rise in hate crimes against Muslims combined with Islamophobic rhetoric in media outlets (Dunn et al., 2007; Kalek et al., 2010), the purpose of this study is to examine the relationship between religious discrimination and life satisfaction in a sample of Muslim Americans. Based on a minority stress framework, we considered both distal (religious discrimination) and proximal stressors (fear for safety) commonly experienced by Muslim Americans and first proposed that two different forms of religious discrimination (religious prejudice and environmental religious discrimination) would positively relate to fear for safety and negatively relate to life satisfaction among Muslim Americans. Second, we hypothesized that fear for safety would at least partially mediate the relationships between the two forms of religious discrimination and life satisfaction.

\section{Methods}

\section{Participants}

All recruitment and data collection took place online. The sample consisted of 192 participants who were on average 27.87 years-old ( $S D=10.34)$. Women made up $74.5 \%(143)$ of the study sample, men $24.5 \%$ (47), and $1.0 \%$ (2) chose not to identify. In terms of participants' racial-ethnic background, 40.6\% (78) identified as Middle Eastern/North African, 29.7\% Asian (57), 10.4\% Black/ African American (20), 8.9\% White/European (17), 6.8\% Multiracial/Multiethnic (13), and 3.6\% Hispanic (7). The majority of participants identified as heterosexual $(91.7 \%, 176)$ whereas $3.1 \%$ 
(6) identified as bisexual, gay $(1.6 \%, 3)$, lesbian $(1.0 \%, 2)$, and $2.5 \%$ (5) chose not to report sexual orientation. Over half $(57.8 \%, 111)$ of participants had undergraduate degrees or higher, $23.4 \%$ (45) were currently in school, $13.0 \%$ (25) had some post-secondary education but did not earn a degree, and $2.1 \%$ (4) had a high school diploma or equivalent. In this sample, the majority of participants $(58.9 \%, 115)$ were born in the United States, and most (98) identified themselves as children of immigrants compared to a small number of participants (17) whose parents were also born in the United States. The remaining participants immigrated to the United States as an adult $(20.3 \%, 39)$ or as an infant or child $(19.8 \%, 38)$. At the time of the study, $33.9 \%$ of participants were located in the Northeast (65), 28.6\% the Midwest (55), 22.4\% the Southeast (43), 10.9\% the West (21), and $4.2 \%$ in the Southwest (8). Sociodemographic characteristics are presented in Table 1.

Table 1. Demographic Information $(\mathrm{N}=192)$

\begin{tabular}{|l|c|}
\hline Variable & \\
\hline Age M (SD) & $27.87(10.34)$ \\
\hline Gender N (\%) & $47(24.5)$ \\
\hline Male & $143(74.5)$ \\
\hline Female & $2(1.0)$ \\
\hline Other & $78(40.6)$ \\
\hline Race/Ethnicity N (\%) & $57(29.7)$ \\
\hline Middle Eastern/North African & $20(10.4)$ \\
\hline Asian & $17(8.9)$ \\
\hline Black/African American & $13(6.8)$ \\
\hline White/European & $7(3.6)$ \\
\hline Multiracial/Multiethnic & $176(91.7)$ \\
\hline Hispanic/Latinx & $5(2.6)$ \\
\hline Sexual Orientation N (\%) & $6(3.1)$ \\
\hline Heterosexual & $5(2.5)$ \\
\hline Gay/Lesbian & \\
\hline Bisexual & $4(2.1)$ \\
\hline Did not report & $25(13.0)$ \\
\hline Level of Education N (\%) & $45(23.4)$ \\
\hline High school diploma or equivalent & $111(57.8)$ \\
\hline Some post-secondary & $39(20.3)$ \\
\hline Currently in school & $38(19.8)$ \\
\hline Undergraduate degree or higher & $17(8.9)$ \\
\hline Generation Status N (\%) & $65(33.9)$ \\
\hline Born outside of U.S., but moved as an adult \\
\hline Born outside of U.S., but moved as infant/child \\
\hline Born in U.S., but parents immigrated & $55(28.6)$ \\
\hline Born in U.S., as well as parents & $21(10.9)$ \\
\hline Region of Residence N (\%) & $82.4)$ \\
\hline Northeast & \\
\hline Midwest & \\
\hline Southeast & \\
\hline West & \\
\hline Southwest & \\
\hline
\end{tabular}




\section{Procedure}

Prior to collecting data, this study was approved by the University of Missouri-Kansas City's Institutional Review Board. Recruitment was conducted via email through listservs, such as APA Division 45 and 17, Muslim Student Associations, Facebook, and the Muslim Mental Health Conference. The email provided a general description of the study and indicated that in order to take part in the study, participants must be: (a) at least 18 years old, (b) a permanent resident or an American citizen, and (c) identify as a Muslim. Interested participants were directed to follow the hyperlink to the Qualtrics survey where they were presented with informed consent information, the purpose of the study, what the results would be used for, and the option (selecting yes) to continue on to the questionnaire portion of the study.

\section{Measures}

Religious discrimination. A modified version of the Religious Discrimination Scale (Rippy \& Newman, 2008) was used to measure the distal stressor of religious discrimination. The Religious Discrimination scale was modeled off the Race-Related Stressor Scale (Loo et al., 2001) which assesses a multidimensional model of discriminatory stress (e.g., individual, institutional, and cultural) among Asian Americans. Rippy and Newman (2008) generated items for the Religious Discrimination Scale based on individual interviews, focus groups, and expert review. Overall, the Religious Discrimination Scale consists of 33 items across three subfactors: (a) Prejudice and Stigmatization, (b) Racist Environment, and (c) Bicultural Identification; however, Bicultural Identification was omitted in the current study given that this subscale included items that specifically targeted individuals who identify as Iraqi or Afghani rather than just their faith.

The Prejudice and Stigmatization subscale (hereinafter referred to as religious prejudice) consists of 21 items that measure the degree to which participants report experiencing discrimination based on their Muslim identity (e.g., "Have fellow Americans ever kept their physical distance from you because of the fact you were Muslim?") whereas the Religious Discrimination-Racist Environment Subscale (hereinafter referred to as environmental religious discrimination) consists of six items and measures discrimination experienced from exposure to mainstream media (e.g., "Have you ever heard Muslims referred to in a derogatory term in the media (newspaper, television, films, internet, or radio commentators?"). Participants are asked to rate each item using a scale from 1 (disagree) to 4 (agree). Subscale scores are calculated by summing the items for each and can range from 21 to 84 for religious prejudice and from 6 to 24 for environmental religious discrimination. For the current sample, scores on both the religious prejudice and environmental religious discrimination subscales demonstrated adequate estimates of internal consistency $(\alpha=$ 0.91 and $\alpha=0.87$, respectively) which were comparable to values in the original study sample of Muslim Americans (Rippy \& Newman, 2008). In support of concurrent validity, Rippy and Newman (2008) found that the total score of religious discrimination significantly related to PTSD symptomology $(r=.35)$ and self-reported acts of hate $(r=.45)$. In the current study, the correlation between religious prejudice and environmental religious discrimination was $r=.58$ which was similar to that of the original study $(r=.44)$.

Fear for safety. At the time of this study's creation, there were no published measures that assessed fear for safety among Muslim Americans or other racial-ethnic minority groups. Therefore, we developed a 15-item measure to assess fear for safety among Muslims within the context of American society. Items were developed based on an extensive review of empirical research on the discriminatory experiences of Muslim Americans (i.e., Abu-Ras \& Suarez, 2009; Al Wazni, 2015; Ghaffari \& Çiftçi, 2012) as well as survey reports (CAIR, 2015; 2018; Ibish, 2008; Lipka, 2017). Example sample items include: “As a Muslim American, I am concerned about not 
being protected by police" and "As a Muslim American, I am concerned about being physical harassed". Participants were asked to rate each item using a six-point scale ranging from 1 (strongly disagree) to 6 (strongly agree). Scores were summed up to create a total fear for safety score which could range from 15 and 90 . In the current sample, scores demonstrated an adequate estimate of internal consistency $(\alpha=.89)$. To establish initial evidence for concurrent validity, fear for safety scores were correlated with the two forms of religious discrimination. Specifically, participants who reported a higher fear for safety also reported more experiences with religious prejudice $(r=.59)$ and environmental religious discrimination $(r=.58)$.

Life satisfaction. The Satisfaction with Life Scale (SWLS; Diener, Emmons, Larsen, \& Griffin, 1985) was utilized to measure life satisfaction. The measure consists of five items (e.g., In most ways my life is close to my ideal) and participants are asked to rate each on a seven-point scale, ranging from 1 (strongly disagree) to 7 (strongly agree). Total scores can range from 5 to 35 . Abu-Rayya, Almoty, White, and Abu-Rayya (2016) found that scores on the SWLS demonstrated an adequate estimate of reliability $(\alpha=.84)$ among a sample of Australian Muslims.

Demographic information. Participants were asked to provide basic demographic information about themselves, including age, gender, racial-ethnic background, sexual orientation, region of residence, annual household income, level of education, generational status, and whether they were born into a Muslim family. Participants were also asked to provide the number of years they have been practicing Islam.

\section{Data Analysis Plan}

Data screening and preliminary analysis. Before testing the hypothesized model, data was screened for missing data and other conditions for linear regression. Of the 255 participants who accessed the survey, 60 were removed for missing over $20 \%$ of data. Analysis of missing data revealed the percentage of missing data was deemed low (.03). Overall, the final sample included 192 participants. In addition, all scores were normally distributed. Standardized residuals for each calculated regression fell within acceptable ranges ( -3 to 3 ). Mahalanobis and Cook's distances and leverage values indicated no presence of outliers. Values for tolerance and inflation fell within acceptable ranges (tolerance $=0.57$ to 0.86 ; VIF $=1.16$ to 1.72 ) indicating that multicollinearity was not a concern.

Multivariate tests were also used to examine potential differences in group means based on participants' racial-ethnic background, gender, and generational status. Results revealed no significant multivariate effects based on racial-ethnic background or generational status; however significant effects were found for gender $(F(2,181)=3.06, p=.002$, Pillai's Trace $=$ $\left..128, \eta \mathrm{p}^{2}=.064\right)$ that were specific to fear for safety, $F(2,181)=-9.14, p<.001$. Bonferroni adjusted $95 \%$ confidence intervals revealed that women expressed higher concerns for safety $(M=48.46, S D=9.91)$ compared to men $(M=39.31, S D=13.43)$.

\section{Results}

Bivariate correlations were used to test Hypothesis 1, which proposed that scores on the dimensions of religious discrimination (religious prejudice and environmental religious discrimination) would significantly and positively relate to fear for safety and negatively relate to life satisfaction among Muslim Americans. Both religious prejudice and environmental religious discrimination significantly and positively related to fear for safety $(r=.55, p<.001 ; r=.56, p<$ $.001)$ respectively. Overall, the results of the correlational analysis indicated that all relationships between variables were significant and in the expected direction (Table 2). Given that participant age was significantly related to both religious discrimination variables, fear for safety, as well as life satisfaction, age was entered as a covariate in the remaining study analyses. 
Table 2. Correlations, Means, and Standard Deviations of Variables of Interest

\begin{tabular}{|l|c|c|c|c|c|c|r|}
\hline & $\mathbf{1}$ & $\mathbf{2}$ & $\mathbf{3}$ & $\mathbf{4}$ & $\mathbf{5}$ & $\mathbf{M}$ & SD \\
\hline 1. Religious prejudice & & & & & & 39.33 & 13.84 \\
\hline $\begin{array}{l}\text { 2. Environmental } \\
\text { discrimination }\end{array}$ & $.54^{* * *}$ & & & & & 19.47 & 4.57 \\
\hline 3. Fear of safety & $.55^{* * *}$ & $.56^{* * *}$ & & & & 50.82 & 12.41 \\
\hline 4. Life satisfaction & $-.24^{* * *}$ & $-.19^{* *}$ & $-.39^{* * *}$ & & & 23.58 & 5.95 \\
\hline 5. Religious identity & $.51^{* * *}$ & $.56^{* * *}$ & $.49^{* * *}$ & $.19^{* *}$ & & 36.22 & 5.91 \\
\hline 6. Age & $-.17^{*}$ & $-.24^{* * *}$ & $-.20^{* *}$ & $.25^{* * *}$ & $-.19^{*}$ & 27.87 & 10.34 \\
\hline
\end{tabular}

$* p<.05,{ }^{* *} p<.01,{ }^{* * *} p<.001$.

To test hypothesis 2, we used PROCESS, an SPSS macro that enables testing of models that combine mediation and moderation, effect sizes for indirect effects, and probing for interaction effects (Hayes, 2013). Model 4 was used to test when controlling for participant age, fear for safety would at least partially mediate the relationships between the two forms of religious discrimination (religious prejudice and environmental religious discrimination) and life satisfaction. When fear for safety was entered as a mediator between religious prejudice and life satisfaction, the path between fear safety and life satisfaction was negative and significant $(\beta=-.35, p<.001)$ and the direct path from religious prejudice to life satisfaction became non-significant $(\beta=-.04, p=.63)$, suggesting a partial mediation effect. To test the significance of the indirect effect $(\beta=-.18), 95 \%$ bias-corrected confidence intervals were estimated and revealed the absence of zero (CI:-.27, -.10), suggesting that the partial indirect effect of religious prejudice on life satisfaction through fear for safety was significant (see Figure 1).

The same model was used to test the effect of environmental religious discrimination on life satisfaction through fear for safety when controlling for participant age. When entered into the equation as a mediator, the path between fear for safety and life satisfaction was negative and significant $(\beta=-.38, p<.001)$ and the direct path from environmental religious discrimination to life satisfaction became non-significant $(\beta=.02, p=.835)$, suggesting a partial mediation effect. To test the significance of the indirect effect $(\beta=-.20), 95 \%$ bias-corrected confidence intervals were estimated and revealed the absence of zero (CI: $-.28,-.12)$, suggesting that the partial indirect effect of environmental religious discrimination on life satisfaction through fear for safety was significant (see Figure 2). Overall, hypothesis 2 was supported.

\section{Discussion}

In an effort to help elucidate the discriminatory experiences of Muslim Americans particularly within the recent climate of heightened Islamophobia, the purpose of the current study was to examine the relationship between religious discrimination and wellbeing in a sample of adult Muslim Americans. Given the current sociopolitical context of Islamophobia that serves to stereotype Muslims as a singular and uniform group (Wang et al., 2019), we considered two distal stressors that included targeted experiences of prejudice (religious prejudice) as well as discriminatory messages through the media (environmental religious discrimination). Based on the framework of minority stress theory (Meyer, 1995; 2003), we expected that Muslim Americans who experienced high levels of religious discrimination would contribute as a proximal stressor and appraise their experiences as threatening to their safety, which in turn would have negative consequences on their wellbeing. 


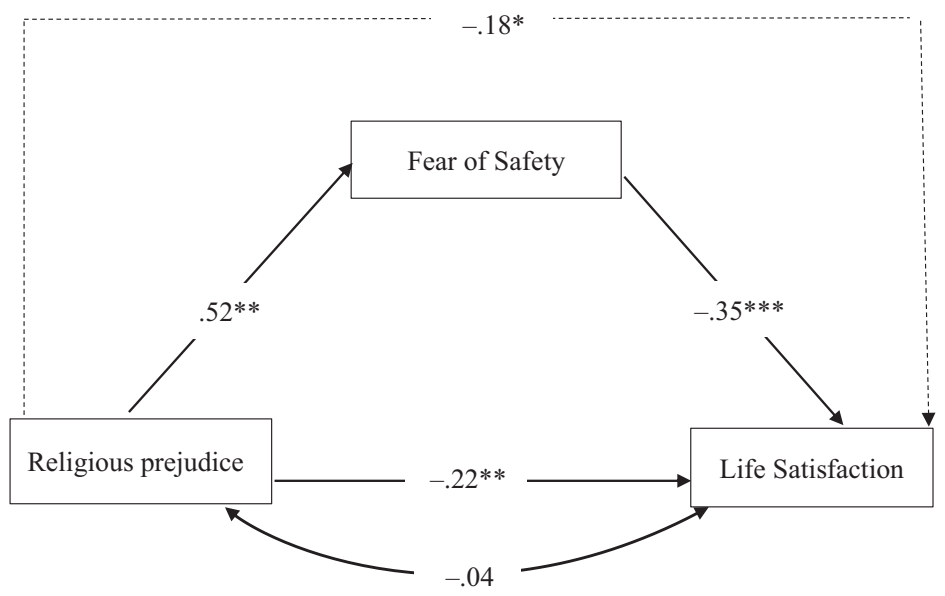

Figure 1. Direct and indirect effects of religious prejudice on life satisfaction

$* p<.05^{* *} p<.01 * * * *<<.001$.

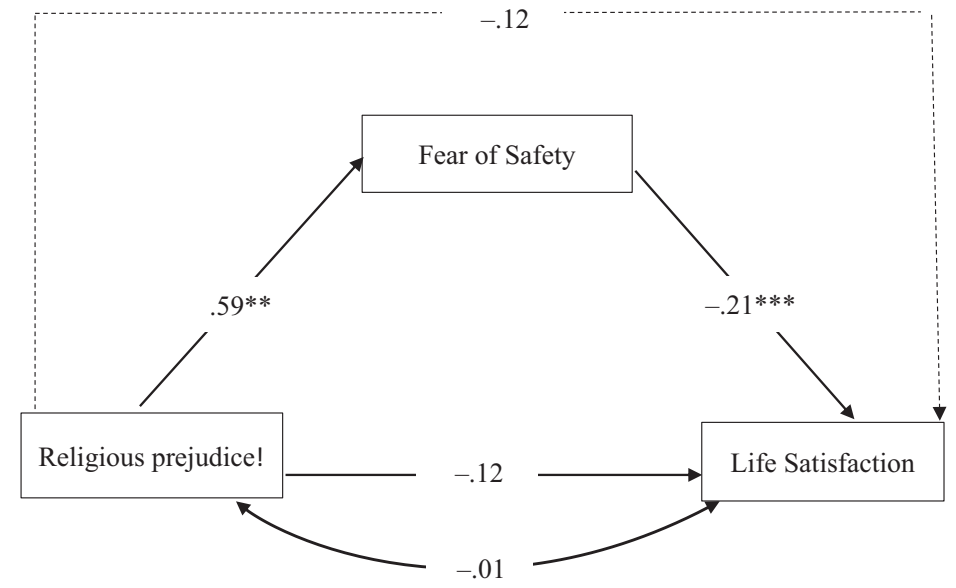

Figure 2. Direct and indirect effects of environmental discrimination on life satisfaction

${ }^{*} p<.05^{* *} p<.01 * * * *<.001$.

Overall, participants who faced higher rates of environmental religious discrimination and prejudice also reported lower levels of life satisfaction. These findings are consistent with prior research indicating that Muslim Americans who face high rates of discrimination also tend to experience poor mental health outcomes as evidenced by higher rates of depression (Hodge et al., 2016), anxiety, and PTSD (Abu-Ras \& Suarez, 2009; Lowe et al., 2019; Nadal et al., 2012). Importantly, study results also help underscore the significance of media-based discrimination. Although studies suggest that Muslim communities are indeed affected by the political climate based on indicators of social engagement and national identity (Kunst et al., 2012), current study results speak to the ongoing prevalence and denigrating impact of anti-Muslim sentiments in mainstream media and other public outlets.

Although minority stress theory was originally created for sexual minorities, this study's results provide some evidence in support of minority stress theory's applicability with other groups, such that based on their experiences with both forms of discrimination (distal stressor), 
participants were more likely to express fear for their safety (proximal stressor) and in turn were more likely to report lower rates of life satisfaction. In particular, participants who experienced high levels of individualized prejudice as well as discrimination through the mainstream media appraised their sense of safety as being compromised and reported lower life satisfaction. Based on the results of the present study, minority stress theory has been shown to be generalizable to this Muslim population. Although prior studies have certainly documented that fear for safety is a significant concern among Muslim and Arab communities (Abu-Ras \& Abu-Bader, 2008; Ali et al., 2008), current study results suggest that fear for safety may help explain the link between experiencing discrimination and adverse outcomes among Muslim Americans. As a proximal stressor, fear for safety is considered to be more subjective and related to personal identity, which may vary depending on the individual (Meyer, 2003). Results suggest that participants in the current study expressed significant concern for their safety as Muslim Americans, which helped partially explained the link between both forms of religious discrimination and lower life satisfaction. It is important to note that in the current study, women made up $76 \%$ of the sample and also reported significantly higher concerns for safety compared to men ( $M=48.46$ vs. $M=$ 39.31). These results are consistent with prior studies that suggest women, in general, feel less safe in public compared to men, as well as hijabi Muslim women feeling less safe due to their visible Muslim identity (Al Wazni, 2015; Ghaffari \& Çiftçi, 2010; Zaal et al., 2007).

\section{Limitations and Implications for Future Research}

The results of this study should be interpreted within the context of certain limitations that center on sampling restrictions and psychometric limitations. In particular, participants were recruited based on their connections with professional listservs and organizations that were specifically aimed at supporting Muslim students and professionals and Muslim mental health. As suggested by Amer and Bagasra (2013), it is likely that studies on Muslim mental health are impacted by selective sampling given that some Muslims are drawn to such studies while others may avoid participating in research due to the stigma traditionally associated with the field of psychology (Ali et al., 2004; Brown et al., 2010). Based on their involvement, sample participants may have had ongoing exposure to information about mental health and Islamophobia and were therefore more motivated to answer questions about mental health. Similar to the general population of Muslim Americans, study participants were also racially and ethnically diverse, yet they were not specifically asked about their experiences with racial discrimination or their specific religious affiliations. Researchers are encouraged to account for intragroup religious diversity and include measures of racial discrimination given that participants' experiences may have varied based on their racial-ethnic identity as well as their exact religious affiliation (e.g., Sunni, Shia, observant, secular, etc.). In addition to the psychometric limitations of the EIS, scores based on the fear for safety measure should be interpreted with caution given that these items were created for the specific purpose of the current study. As indicated by Amer and Bagasra (2013), the conceptual validity of modifying existing Westernized measures for use among Muslim samples remains questionable without the use of sufficient theory and psychometric support.

\section{Mental Health Implications}

Overall, the results of the current study may provide some important implications for mental health practitioners who work with Muslim Americans. In particular, findings suggest that Muslim Americans are not immune to the social-political climate of increased Islamophobia and experience religious discrimination in different ways. Practitioners and other professionals who 
work with individuals from the Muslim community are encouraged to consider the chronic and ongoing impact of stress that Muslim Americans are facing especially within the context of the United States. In particular, given that mental health services are largely viewed as encapsulating Westernized values (Amer \& Bagasra, 2013), practitioners are encouraged to connect with community advocates to help identify innovative ways of connecting with the Muslim American community. Given that the Muslim American community is incredibly diverse based on specific religious affiliation, racial-ethnic background, and generational status (Wang et al., 2019), practitioners should look for opportunities to connect with Muslim individuals in non-clinical settings. In addition to learning more about the Muslim community and their needs, practitioners and community advocates could offer services to help validate their experiences with religious discrimination while also decreasing the stigma surrounding mental health. Furthermore, mental health practitioners may be able to help Muslim clients cope by addressing their fear for safety while also advocating for changes in their environment (i.e., signs, symbols, messaging, etc.) to help minimize the fear that many Muslims Americans may face in their daily lives.

\section{References}

Abu-Ras, W., \& Abu-Bader., S. H. (2008). The impact of the September 11, 2001, attacks on the well-being of Arab Americans in New York City. Journal of Muslim Mental Health, 3, 217-239. https://doi.org/10.1080/15564900802487634.

Abu-Ras, W. M., \& Suarez,Z. E. (2009). Muslim men and women's perception of discrimination, hate crimes, and PTSD symptoms post 9/11. Traumatology, 15, 48-63. https://doi.org/10.1177/ 1534765609342281

Abu-Rayya, H. M., Almoty, S., White, F. A., \& Abu-Rayya, M. H. (2016). The interconnection between Islamic religiosity and deviancy among Australian Muslim youth: A partial mediation role of life satisfaction. International Journal for the Psychology of Religion, 26(4), 337-347. https:// doi.org/10.1080/10508619.2016.1157720

Ahmad, M. (2009). Muslims and the contestations of religio-political space in America. Policy Perspectives, 6,47-62. https://www-jstor-org.proxy.library.umkc.edu/stable/42909224

Al Wazni, A. B. (2015). Muslim women in America and hijab: A study of empowerment, feminist identity, and body image. Social Work, 60, 325-333. https://doi.org/10.1093/sw/swv033

Ali, S. R., Liu, W. M., \& Humedian, M. (2004). Islam 101: Understanding the religion and therapy implications. Professional Psychology: Research and Practice, 3, 635-642. https://doi.org/10.1037/ 0735-7028.35.6.635

Ali, S. R., Mahmood, A., Moel, J., Hudson, C., \& Leathers, L. (2008). A qualitative investigation of Muslim and Christian women's views of religion and feminism in their lives. Cultural Diversity and Ethnic Minority Psychology, 14, 38-46. https://doi.org/10.1037/1099-9809. 14.1.38

Amer, M. M., \& Bagasra, A. (2013). Psychological research with Muslim Americans in the age of Islamophobia: Trends, challenges, and recommendations. American Psychologist, 68, 134-144. https://doi.org/10.1037/a0032167

Bakalian, A., \& Bozorgmehr, M. (2011). Middle Eastern and Muslim American studies since 9/11. Sociological Forum, 26, 714-728. https://doi.org/10.1111/j.1573-7861.2011.01273.x

Brown, A., Abernethy, A., Gorsuch, R., \& Dueck, A. C. (2010). Sacred violations, perceptions of injustice, and anger in Muslims. Journal of Applied Social Psychology, 40, 1003-1027. https://doi. org/10.1111/j.1559-1816.2010.00608.x 
Cainkar, L. (2002). No longer invisible: Arab and Muslim exclusion after September 11. Middle East Report, 224, 22-29. https://doi.org/10.2307/1559419

Carr, D., \& Friedman, M. A. (2005). Is obesity stigmatizing? Body weight, perceived discrimination, and psychological well-being in the United States. Journal of Health and Social Behavior, 46, 244-259. https://doi.org/10.1177/002214650504600303

Council on American-Islamic Relations. (2015). CAIR reports unprecedented backlash against American Muslims after Paris attacks. https://www.cair.com/press-center/press-releases/13277-cair-reportsunprecedented-backlash-against-american-muslims-after-paris-attacks.html

Council on American-Islamic Relations. (2018). CAIR report: Anti-Muslim bias incidents, hate crimes spike in second quarter of 2018. https://www.cair.com/cair_report_anti_muslim_bias_incidents_ hate_crimes_spike_in_second_quarter_of_2018

Diener, E., Emmons, R. A., Larsen, R. J., \& Griffin, S. (1985). The Satisfaction with Life Scale. Journal of Personality Assessment, 49, 71-75. https://doi.org/10.1207/s15327752jpa4901_13

Dunn, K. M., Klocker, N., \& Salabay, T. (2007). Contemporary racism and Islamophobia in Australia: Racializing religion. Ethnicities, 7, 564-589. https://doi.org/10.1177/1468796807084017

Every, D., \& Perry, R. (2014). The relationship between perceived religious discrimination and self-esteem for Muslim Australians. Australian Journal of Psychology, 66, 241-248. https://doi. org/10.1111/ajpy.12067

Ghaffari, A., \& Çiftçi, A. (2010). Religiosity and self-esteem of Muslim immigrants to the United States: The moderating role of perceived discrimination. International Journal for the Psychology of Religion, 20, 14-25. https://doi.org/10.1080/10508610903418038

Hayes, A. F. (2013). Introduction to Mediation, Moderation, and Conditional Process Analysis: A RegressionBased Approach. New York: Guilford Press.

Hodge, D. R., Zidan, T., \& Husain, A. (2016). Depression among Muslims in the United States: Examining the role of discrimination and spirituality as risk and protective factors. Social Work, 61, 45-52. https://doi.org/10.1093/sw/swv055

Hood, P. (2009). Modest rise in concern about Islamic extremism. Washington DC: Pew Research Center; 2009. https://www.pewresearch.org/wp-content/uploads/sites/4/legacy-pdf/564.pdf

Ibish, H. (2008). Report on hate crimes and discrimination against Arab Americans: 2003-2007. Washington, DC: American-Arab Anti-Discrimination Committee. www.issuelab.org/ resource/20032007_report_on_hate_crimes_and_discrimination_against_arab_americans

Kalek, S., Mak, A. S., \& Khawaja, N. G. (2010). Intergroup relations and Muslims' mental health in western societies: Australia as a case study. Journal of Muslim Mental Health, 5, 160-193. https:// doi.org/10.1080/15564908.2010.487722

Kira I. A., Lewandowski L., Templin T., Ramaswamy V., Ozkan B., \& Mohanesh J. (2010). The effects of perceived discrimination and backlash on Iraqi refugees' mental and physical health. Journal of Muslim Mental Health, 5, 59-81. https://doi.org/10.1080/15564901003622110

Kunst, J. R., Tajamal, H., Sam, D. L., \& Ulleberg, P. (2012). Coping with Islamophobia: The effects of religious stigma on Muslim minorities' identity formation. International Journal of Intercultural Relations, 36, 518-532. https://doi.org/10.1016/j.jiintrel.2011.12.014

Laird, L. D., Abu-Ras, W., \& Senzai, F. (2013). Cultural citizenship and belonging: Muslim international medical graduates in the USA. Journal of Muslim Minority Affairs, 33, 356-370. https://doi. org/10.1080/ 13602004.2013.863075 
Lehavot, K., \& Simoni, J. M. (2011). The impact of minority stress on mental health and substance use among sexual minority women. Journal of Consulting and Clinical Psychology, 79, 159-170. https:// doi.org/10.1037/a0022839

Lipka, M. (2017). Muslims and Islam: Key findings in the US and around the world. Washington, DC: Pew Research Center; 2015. http://pewrsr.ch/2s2KmpU

Loo, C. M., Fairbank, J. A., Scurfield, R. M., Ruch, L. O., King, D. W., Adams, L. J. et al. (2001). Measuring exposure to racism: Development and validation of a Race-Related Stressor Scale (RRSS) for Asian American Vietnam veterans.

Psychological Assessment, 13, 503-520. https://doi.org/10.1037/1040-3590.13.4.503

Lowe, S. R., Tineo, P., Bonumwezi, J. L., \& Bailey, E. J. (2019). The trauma of discrimination: Posttraumatic stress in Muslim American college students. Traumatology, 25, 115-123. https://doi. org/10.1037/trm0000197

Major, B., Kaiser, C. R., O’Brien, L. T., \& McCoy, S. K. (2007). Perceived discrimination as worldview threat or worldview confirmation: Implications for self-esteem. Journal of Personality and Social Psychology, 92, 1068-1086. https://doi.org/10.1037/0022-3514.92.6.1068

Mendoza-Denton, R., Downey, G., Purdie, V. J., Davis, A., \& Pietrzak, J. (2002). Sensitivity to status-based rejection: Implications for African American students' college experience. Journal of Personality and Social Psychology, 83, 896-918. https://doi.org/10.1037/0022-3514.83. 4.896

Mercier, B., Norris, A., \& Shariff, A. F. (2018). Muslim mass shooters are perceived as less mentally ill and more motivated by religion. Psychology of Violence, 8, 772-781. https://doi.org/10.1037/ vio0000217

Meyer, I. H. (1995). Minority stress and mental health in gay men. Journal of Health and Social Behavior, 36, 38-56. https://doi.org/10.2307/2137286

Meyer, I. H. (2003). Prejudice, social stress, and mental health in lesbian, gay and bisexual populations: Conceptual issues and research evidence. Psychological Bulletin, 129, 674-697. https://doi. org/10.1037/0033-2909.129.5.674

Mohamed, B. (2016). A new estimate of the U.S. Muslim population. Washington, DC: Pew Research Center. http://pewrsr.ch/1PfaUs5

Nadal, K. L., Griffin, K. E., Hamit, S., Leon, J., Tobio, M., \& Rivera, D. P. (2012). Subtle and overt forms of Islamophobia: Microaggressions toward Muslim Americans. Journal of Muslim Mental Health, 6, 15-37. https://doi.org/10.3998/jmmh.10381607.0006.203

Parent, M. C., Brewster, M. E., Cook, S. W., \& Harmon, K. A. (2018). Is minority stress in the eye of the beholder? A test of minority stress theory with Christians. Journal of Religion and Health, 57(5), 1690-1701. https://doi.org/10.1007/s10943-017-0550-6

Pascoe, E. A., \& Smart Richman, L. (2009). Perceived discrimination and health: A meta-analytic review. Psychological Bulletin,135, 531-554. https://doi.org/10.1037/a0016059

Pearlin, L. I., Turner, H., \& Semple, S. (1989). Coping and the mediation of caregiver stress. In E. Light \& B. D. Lebowitz (Eds.), Alzheimer's disease treatment and family stress: Directions for research. (pp. 198-217).

Pew Research Center. (2018). Muslims in America: Immigrants and those born in U.S. see life differently in many ways. https://www.pewforum.org/essay/muslims-in-america-immigrants-and-thoseborn-in-u-s-see-life-differently-in-many-ways/

Platt, L. (2007). Poverty and ethnicity in the UK. Bristol, UK: Policy Press. 
Rippy, A. E., \& Newman, E. (2006). Perceived religious discrimination and its relationship to anxiety and paranoia among Muslim Americans. Journal of Muslim Mental Health, 1, 5-20. https://doi. org $/ 10.1080 / 15564900600654351$

Rippy, A. E., \& Newman, E. (2008). Adaptation of a Scale of Race-Related Stress for use with Muslim Americans. Journal of Muslim Mental Health, 3, 53-68. https://doi.org/10.1080/15564900802035292

Rosentiel, R. (2007). Muslim Americans: Middle class and mostly mainstream. Washington, DC: Pew Research Center. https://www.pewresearch.org/wp-content/uploads/2007/05/muslim-americans. pdf

Rubenstein, W. B. (2004). The real story of U.S. hate crimes statistics: An empirical analysis. Tulane Law Review, 78, 1213-1246.

Schmitt, M. T., Branscombe, N. R., Postmes, T., \& Garcia, A. (2014). The consequences of perceived discrimination for psychological well-being: A meta-analytic review. Psychological Bulletin, 140, 921-948. https://doi.org/10.1037/a0035754

Shaver, J. H., Sibley, C. G., Osborne, D., \& Bulbulia, J. (2017). News exposure predicts anti-Muslim prejudice. PLOS ONE, 12, 1-19. https://doi.org/10.1371/journal.pone.0174606

Sheridan, L. P. (2006). Islamophobia pre- and post-September $11^{\text {th }}, 2001$. Journal of Interpersonal Violence, 21, 317-336. https://doi.org/10.1177/0886260505282885

Wang, S. C., Raja, A. H., \& Azhar, S. (2019). "A lot of us have a very difficult time reconciling what being Muslim is": A phenomenological study on the meaning of being Muslim American. Cultural Diversity and Ethnic Minority Psychology. https://doi.org/10.1037/cdp0000297

Williams, T., Connolly, J., Pepler, D., \& Craig, W. (2005). Peer victimization, social support, and psychosocial adjustment of sexual minority adolescents. Journal of Youth and Adolescence, 34, 471-482. https://doi.org/10.1007/s10964-005-7264-x

Williams, D. R., Neighbors, H. W., \& Jackson, J. S. (2008). Racial/ethnic discrimination and health: Findings from community studies. American Journal of Public Health, 93, 200-208. https://doi. org/10.2105/AJPH.93.2.200

Younis, M. (2015). "Perceptions of Muslims in the United States: A review”. https://news.gallup.com/ opinion/gallup/187664/perceptions-muslims-united-states-review.aspx

Zaal, M., Salah, T., \& Fine, M. (2007). The weight of the hyphen: Freedom, fusion and responsibility embodied by young Muslim-American women during a time of surveillance. Applied Developmental Science, 11, 164-177. https://doi.org/10.1080/10888690701454674 